\title{
Virtual Simulators: A Tool for Current Dental Education. Integrative
}

Review*

\begin{abstract}
Simuladores virtuales: una herramienta para la educación odontológica actual. Revisión integrativa
\end{abstract}

Simuladores virtuais: uma ferramenta para a educação odontológica atual. Revisão integrativa

Submission date: 28-07-2020 | Acceptance date: 21-12-2020

\begin{abstract}
Michelle Morón Araújo
Pontificia Universidad Javeriana, Bogotá, Colombia. michellemoronaraujo@gmail.com; https://orcid.org/0000-0003-1523-3811
\end{abstract}

Correspondence: michellemoronaraujo@gmail.com

* Original documental research. Integrative review of literature

doi: https://doi.org/10.11144/Javeriana.uo39.vsde

How to cite: Morón Araújo M. Virtual Simulators: A Tool for Current Dental Education. Integrative Review. Univ Odontol. 2020; 39. https://doi.org/10.11144/Javeriana.uo39.vsde 


\section{ABSTRACT}

Background: In the wake of the COVID-19 pandemic, the use of virtual reality in education has increased. However, it is necessary to better understand its possibilities, precision, and user perception for the development of dental teaching. Purpose: To analyze current literature about virtual reality simulation and its implementation in dental education. Methods: Articles listed in different databases (PubMed, Cochrane, Javeriana University library catalog, and SciELO) describing studies on the use of virtual simulators in dentistry teaching were identified and reviewed. Articles published between 2010 and 2020 were reviewed. Results: From a total of 1030 titles identified, 13 articles were selected to conduct the integrative review. Most of the articles were evaluations of specific cohorts who received training, mainly related to preclinical activities. Some studies were controlled clinical trials and other qualitative evaluations. Only one study had a two-year longitudinal design. In all cases, the results and perception of virtual reality simulation were positive. Conclusions: The virtual reality simulation methodology shows promising results for dental teaching.

\section{Keywords}

COVID-19; dental education; dentistry; educational technology; haptic technology; integrative review; simulation with virtual reality; virtual reality; virtual simulator

\section{RESUMEN}


Antecedentes: A raíz de la pandemia del COVID-19, el uso de la realidad virtual en la educación se ha incrementado. Sin embargo, hace falta conocer mejor sus posibilidades, precisión y percepción de los usuarios para el desarrollo de la docencia odontológica. Objetivo: Analizar literatura actual acerca de la simulación con realidad virtual y su implementación en la educación odontológica. Métodos: Se identificaron y revisaron artículos listados en diferentes bases de datos (PubMed, Cochrane, catálogo de la biblioteca de la Universidad Javeriana y SciELO) que describieran estudios sobre el uso de simuladores virtuales en la enseñanza en odontología. Se revisaron artículos publicados entre 2010 y 2020. Resultados: De un total de 1030 títulos identificados, se seleccionaron 13 artículos para la revisión integrativa. La mayoría de los artículos eran evaluaciones de cohortes específicas que recibieron entrenamientos, principalmente relacionados con actividades preclínicas. Algunos estudios fueron ensayos clínicos controlados y otros evaluaciones cualitativas. Un solo estudio tuvo un diseño longitudinal a dos años. En todos los casos los resultados y percepción de la simulación con realidad virtual fueron positivos. Conclusiones: La metodología de la simulación con realidad virtual muestra resultados promisorios para la enseñanza odontológica.

\section{Palabras clave}

COVID-19; educación odontológica; odontología; realidad virtual; revisión integrativa; simulación con realidad virtual; simulador virtual; tecnología háptica; tecnología educativa

\section{RESUMO}


Antecedentes: Na esteira da pandemia COVID-19, o uso da realidade virtual na educação aumentou. No entanto, é necessário conhecer melhor suas possibilidades, precisão e percepção dos usuários para o desenvolvimento do ensino odontológico. Objetivo: Analisar a literatura atual sobre simulação de realidade virtual e sua implementação na educação odontológica. Métodos: foram identificados e revisados artigos listados em diferentes bases de dados (PubMed, Cochrane, catálogo da biblioteca da Universidade Javeriana e SciELO) que descrevem estudos sobre o uso de simuladores virtuais no ensino de odontologia. Foram revisados os artigos publicados entre 2010 e 2020. Resultados: De um total de 1.030 títulos identificados, 13 artigos foram selecionados para a revisão integrativa. A maioria dos artigos eram avaliações de coortes específicas que receberam treinamento, principalmente relacionado a atividades pré-clínicas. Alguns estudos foram ensaios clínicos controlados e outras avaliações qualitativas. Apenas um estudo teve um desenho longitudinal de dois anos. Em todos os casos, os resultados e a percepção da simulação de realidade virtual foram positivos. Conclusões: A metodologia de simulação de realidade virtual apresenta resultados promissores para o ensino odontológico.

\section{Palavras-chaves}

COVID-19; educação odontológica; odontologia; realidade virtual; revisão integrativa; simulação com realidade virtual; simulador virtual; tecnologia educativa; tecnologia háptica

\section{INTRODUCTION}


A dental simulator is a computerized device that allows to reproduce a system. Simulators reproduce sensations and experiences that can actually happen (1). The application of virtual reality simulators has been increasingly identified in activities such as pre-admission assessments, preclinical training, remedial training for less advanced students, and external accreditation of professional licenses. Nevertheless, the incorporation of such simulators with virtual reality in the curricula seems to be well justified today, it is still necessary to carry out studies to confirm their reliability, validity, precision of the different activities and the evaluation of learning (2).

In recent decades, different epidemics and pandemics have shown that human beings are still very vulnerable to infectious diseases. In December 2019, in the city of Wuhan, Hubei province in China, a series of patients with acute respiratory syndrome were reported (3). This new disease that spread to many countries around the world in recent months, the COVID-19 pandemic, has been a situation that has generated a global health and economic crisis. The consequences of social isolation to avoid contagion include physical and mental problems. For the educational sector in particular, the rapid and forced change to virtual teaching has affected dental practice and the training of professionals, who have always relied on face-to-face to teach preclinical and clinical classes (4). Shortly after announcing the need to assume "social distancing" and reducing all contact, education and training programs were deeply affected. The COVID-19 pandemic hit dental education hard. The cessation of preclinical and clinical activities has limited clinical skills learning opportunities for students. Likewise, it has not been possible to continue many of the treatments started (5). 
Virtual online simulators, representing advances in technology and telecommunications, are presented as an opportunity in dental education before a student is faced with real situations in the clinic. The phantom head simulator (mannequin) has been the iconic and leading device for dental education since its inception decades ago. Virtual haptic simulation (simulation of tactile, auditory and visual sensations) in education is innovative and can be implemented in preclinical practices (6). These devices provide benefits such as correct ergonomics and proper handling of the dental mirror and high and low speed handpieces. It also allows the use of adequate fulcrum to maintain stability during instrumentation, a fundamental concept that a beginner must learn before developing more complex skills (7). Simulators with virtual reality provide integrated scenarios of clinical cases in the environment of operational teaching and facilitate tactile diagnostic skills, through the use of haptic technology. In addition to virtual reality simulators that are used as an alternative teaching modality, the experience of using virtual reality has been identified as a more pleasant and enjoyable learning experience. These advances have become more widely known during the lockdown from the pandemic. Dental education has been learning to give more priority to virtuality $(7,8)$.

One of the Sherwood Forest Hospitals in the United States has been one of the pioneering programs to use the Moog Simodont ${ }^{\circledR}$ dental trainer. The Simodont ${ }^{\circledR}$ offers a high-resolution threedimensional image combined with a handpiece that is highly realistic (9). Computer-controlled feedback helps students get a realistic and accurate feel for the objects and materials they are working on. Students can now improve their skills and techniques before moving on to the real thing (9). The combination of phantom head (mannequin) training to acquire dental surgical skills was the method of the early 20th century and is still used in dental schools/colleges. At the end of the 20th century, 
simulations grew in complexity and technology (10). Figure 1 shows a timeline of virtual simulators' development.

FIGURE 1

CHRONOLOGY OF VIRTUAL SIMULATORS IN DENTAL EDUCATION (PREPARED IN SPANISH BY THE AUTHOR)

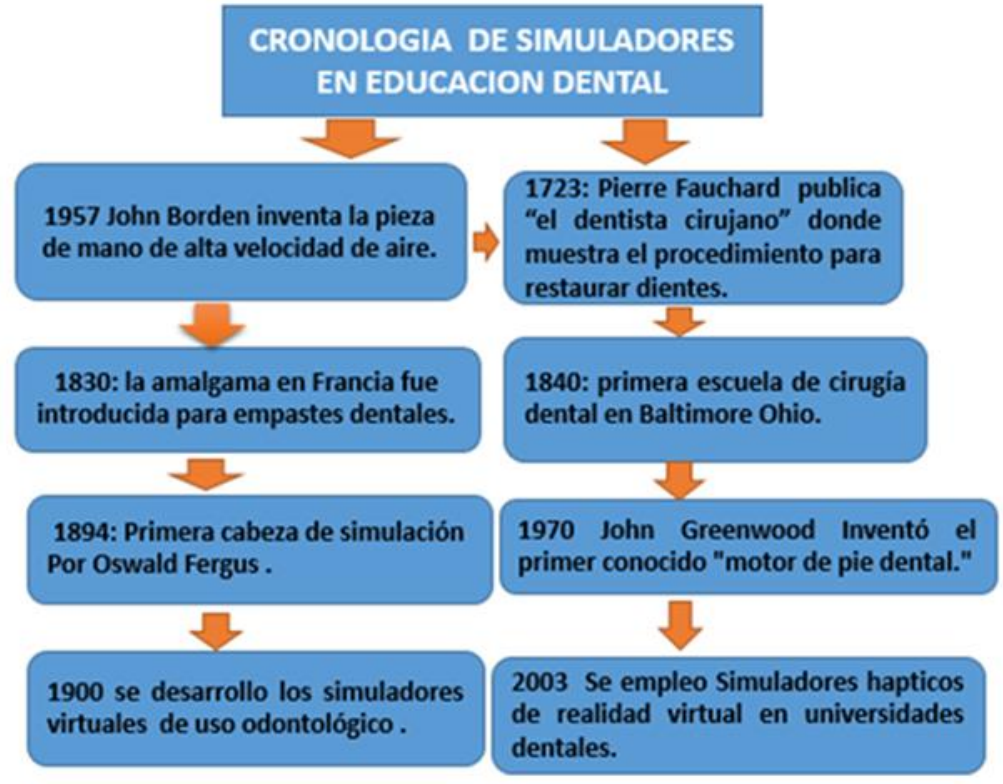

Haptic models are much more profitable for the student and solve the need to invest in physical rotary models and instruments. They also contribute to the economic and environmental sustainability of universities, with the added value of working in pathological environments $(11,12)$. The main known simulators are:

- Enabled haptic dental simulator (Montgomery, Herbranson \& Brown, 2005). It includes teeth obtained by previous scanning with computerized microtomography and high-resolution photographs to generate a $3 \mathrm{D}$ tooth that will provide the user with a sensation or tactile return quite similar to that experienced when a cavity preparation is performed. 
- Dental simulator combining three-dimensional modeling (Kim \& Parque, 2006). It uses polygonal meshes in haptic interaction, arranged for dental probing, diagnosis, and the realization of cavity preparations.

- Virtual Reality Dental Training System (VRDTS®) (Novint Technologies in collaboration with Harvard University School of Dental Medicine, 2007). It uses software that simulates a single molar and its dental tissues (enamel, dentin, pulp, and carious tissue) and a set of dental instruments such as micromotor, explorer, excavators, and materials such as amalgam and cavity cements.

- Iowa Dental Surgical Simulator (IDDSS $®$ ) (joint project of the University of Iowa School of Dentistry and GROK Lab). With this simulator the operator can feel the tactile characteristics of enamel and healthy and carious dentin.

- 3DDental, commercialized by SimuLife®. Designed to provide a lifelike tactile sensation during caries probing, cavity preparation and filling.

- DentSim ${ }^{\circledR}$ (DentSim Lab, NYC). It is considered one of the first dental simulators that has existed. It allows to make dental preparations on artificial tooth models and display the process on a monitor.

- Moog Simodont Dental Trainer (Simodont ${ }^{\circledR}$ ). These simulators began to be used by the Academic Centre for Dentistry Amsterdam (ACTA) since September 2010, as the completion of an experimental study that had begun a year earlier in a small laboratory, where the first six units were installed (11-13).

\section{MATERIALS AND METHODS}


In this integrative literature review, an exhaustive electronic search was carried out in different databases and virtual search engines (PubMed, Cochrane, Javeriana University library catalog, and SciELO). The following combination of keywords was used: "Simulation, virtual" AND "Education, dental." 423 titles were found in PubMed, 171 in Cochrane and SciELO, and 1,397 in the database of the library of the Pontificia Universidad Javeriana in Bogotá, Colombia. A total of 1995 titles were obtained from which repeated and informative medical articles were excluded. Studies published between 2010 and 2020 were included, with a total of 1030 articles. By limiting the search to the years 2019 and 2020, the count dropped to 211 titles. The texts were selected at the discretion of the researcher by title, summary evaluative, experimental, randomized studies, and reviews. The inclusion criteria were: no language limit, full text, years 2010-2020 and priority for 2020 publications. The final sample had a total of 13 articles for the integrative review.

FIGURE 2

SEARCH METHODOLOGY

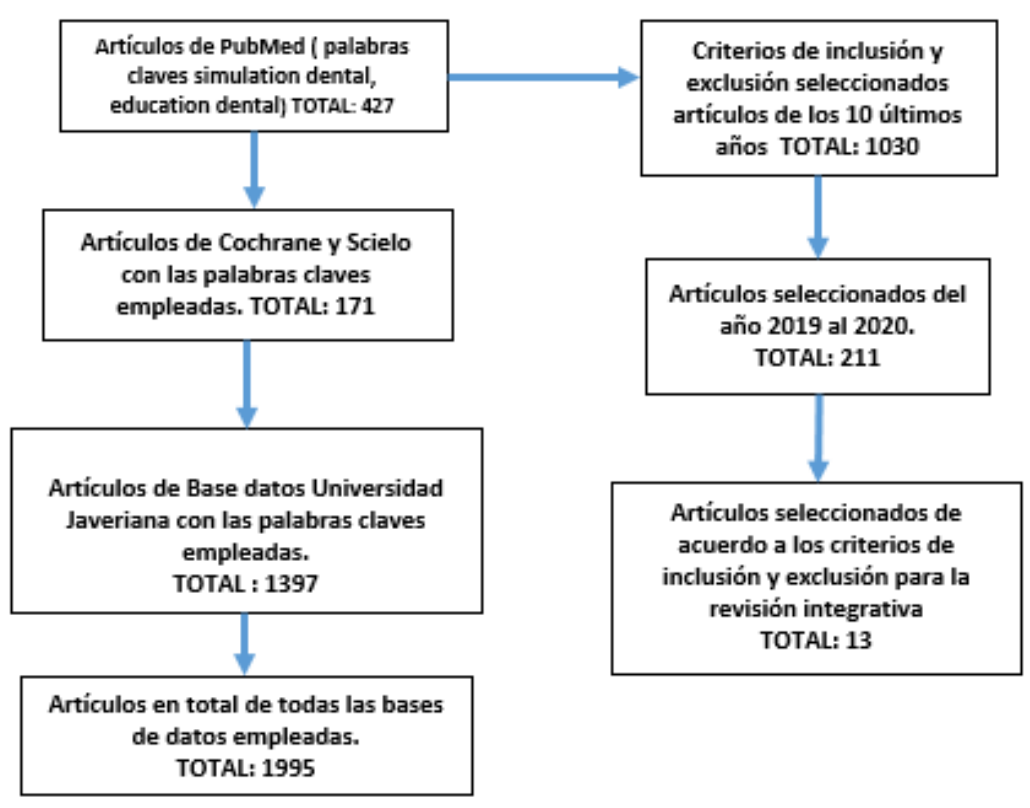




\section{RESULTS}

The content of the 13 articles selected $(6,10,11,13-22)$ to carry out the integrative review of the literature is summarized in Table 1. It includes information on authors, year of publication, type of study, purpose, sample, methods and conclusions. Most of the selected articles were evaluations of educational strategies with specific cohorts that received training with virtual simulators, mainly related to preclinical activities. Some of these activities included making stainless steel crowns in pediatric dentistry, metal and ceramic crowns, cavity preparations, and periodontal probing $(10,13-$ $17,19,21,22)$. Some studies were controlled clinical trials $(14,15,17)$ and other qualitative evaluations $(13,20)$. Only one study had a two-year longitudinal design (22). In all cases, the results, adaptation and perception of the simulation with virtual reality (SVR) were positive $(10,11,13,18,20)$. Evidence that corroborates these observations was analyzed in a review article (6).

TABLE 1

ARTICLES INCLUDED IN THE INTEGRATIVE REVIEW

\begin{tabular}{|c|c|c|c|c|}
\hline Author(s) & $\begin{array}{c}\text { Year, type of } \\
\text { study }\end{array}$ & Purpose & Sample and methods & Results and conclusions \\
\hline $\begin{array}{l}\text { Plessas A. } \\
\text { (6) }\end{array}$ & $\begin{array}{l}\text { 2017, literature } \\
\text { review }\end{array}$ & $\begin{array}{l}\text { To examine the literature } \\
\text { for evidence supporting } \\
\text { the use and role of } \\
\text { augmented vs. } \\
\text { instruction by the } \\
\text { facilitator }\end{array}$ & $\begin{array}{l}\text { A literature search was carried } \\
\text { out on the following databases: } \\
\text { EBSCO, Medline, British } \\
\text { Educational Index and ERIC }\end{array}$ & $\begin{array}{l}\text { SVR can enable better } \\
\text { understanding in a more } \\
\text { diverse learning environment } \\
\text { and augment rather than } \\
\text { replace existing teaching } \\
\text { methods such as instruction } \\
\text { and feedback by instructors }\end{array}$ \\
\hline $\begin{array}{l}\text { Zafar et al. } \\
\text { (10) }\end{array}$ & $\begin{array}{l}2020, \\
\text { cross-sectional } \\
\text { study }\end{array}$ & $\begin{array}{l}\text { To analyze the } \\
\text { perception of students } \\
\text { through a questionnaire } \\
\text { on preclinical pediatric } \\
\text { dentistry training with } \\
\text { Simodont } \circledast \text { and } \\
\text { conventional simulation }\end{array}$ & $\begin{array}{l}100 \text { dental students who } \\
\text { completed pulpotomies and } \\
\text { stainless steel crowns with } \\
\text { Simodont }{ }^{\circledR} \text { and conventional } \\
\text { preclinical laboratory }\end{array}$ & $\begin{array}{l}51 \% \text { agreed with the use of } \\
\text { Simodont } \AA \text { to assist their } \\
\text { learning. } 56 \% \text { perceived that } \\
\text { the Simodont }{ }^{\circledR} \text { facilitated the } \\
\text { understanding of pediatric } \\
\text { dentistry tasks }\end{array}$ \\
\hline $\begin{array}{l}\text { Álvarez y } \\
\text { Coro. (11) }\end{array}$ & $\begin{array}{l}2019, \\
\text { evaluation of } \\
\text { learning } \\
\text { methods }\end{array}$ & $\begin{array}{l}\text { To assess the adaptation } \\
\text { of the students to the use } \\
\text { of the complex simulator }\end{array}$ & $\begin{array}{l}\text { Students enrolled in the second } \\
\text { year of dentistry, biomaterials } \\
\text { subject, at the European } \\
\text { University of Madrid. Assigned } \\
\text { to } 4 \text { groups }\end{array}$ & $\begin{array}{l}\text { They easily adapted to the use } \\
\text { of the complex simulator, } \\
\text { regardless of gender, age and } \\
\text { language of learning }\end{array}$ \\
\hline
\end{tabular}


Fernández 2020

et al. (13) descriptive, quantitative study
To determine the perception on the usefulness of virtual haptic simulators for the practice in dentistry by students, professionals and academics

\begin{tabular}{ll}
\hline $\begin{array}{l}\text { Kikuchi et } \\
\text { al (14) }\end{array}$ & $\begin{array}{l}2013, \\
\text { randomized } \\
\text { controlled trial }\end{array}$
\end{tabular}

Vincent et 2020 al. (15)

randomized controlled trial

\begin{tabular}{|c|c|}
\hline $\begin{array}{l}\text { Rhienmora } \\
\text { et al. (16) }\end{array}$ & $\begin{array}{l}2010, \\
\text { evaluation of } \\
\text { learning } \\
\text { methods }\end{array}$ \\
\hline $\begin{array}{l}\text { Murbay et } \\
\text { al. (17) }\end{array}$ & $\begin{array}{l}2020 . \\
\text { randomized } \\
\text { controlled trial }\end{array}$ \\
\hline
\end{tabular}

$\begin{array}{ll}\text { González et } & 2020, \\ \text { al. (18) } & \begin{array}{l}\text { cross-sectional } \\ \text { study }\end{array}\end{array}$

Yamaguchi 2013, et al. (19) evaluation of learning methods

To assess how virtual

reality simulation (VRS)

with / without instructor feedback influences skills learning

To assess the contribution of virtual reality to the conventional analog training environment

To assess a dental training system with a haptic interface that allows students to practice dental procedures in a virtual environment

To assess the performance of predoctoral students in dentistry with the Moog Simodont ${ }^{\circledR}($ VR) dental trainer in the preclinical To assess the psychometric quality of an instrument for the acceptance of new technologies adapted from the "unified theory of acceptance and use of technology" (UTAUT) model and validate it To assess haptic SVR with repetitive training as a tool for teaching caries removal and periodontal

probing

$\begin{array}{ll}\begin{array}{l}\text { Coro } \\ \text { Montanet } \\ \text { et al. }(20)\end{array} & \begin{array}{l}\text { 2015, action } \\ \text { research; } \\ \text { qualitative, } \\ \text { exploratory, } \\ \text { and descriptive } \\ \text { study }\end{array} \\ \begin{array}{l}\text { Luwei } \text { et } \\ \text { al. }(21)\end{array} & \begin{array}{l}\text { evaluation of } \\ \text { learning } \\ \text { methods }\end{array}\end{array}$

To assess preclinical application of methods with SVR training (cases and role play) and physical simulators

To assess the effectiveness of a preclinical training for the preparation of ceramic crowns using a virtual system in dentistry

127 dental students (IV, V, VI year), dentists and academics. A preclinical exercise and then a class II cavity was performed on a $3 \mathrm{D}$ virtual haptic simulator

43 fifth-year dental students.

Three groups to evaluate

DentSim ${ }^{\circledR}$ with and without feedback

88 first-year dental students at a dental school in France. Two groups to observe caries preparations in virtual simulators

The performance of the users was assessed using hidden Markov models (HMM) that incorporate various data collected by the simulator

32 pre-doctoral students (second year) assigned to two groups: exposed to VR and unexposed

\section{5 dental students}

The UTAUT scale is reliable and has construction factorial validity. The UTAUT model can be used to assess the acceptance of the virtual haptic simulator in dental education

\section{7 students completed 3}

trainings. The following were evaluated: cutting region, number of instances of handpiece overload and total cutting time. 26 students received training to measure pocket depth

22 out of 45 teachers who applied simulated training in the subjects Pediatric Dentistry I and II and Restorative Dentistry II

57 dental students, who prepared ceramic crowns using the Real-Time Dental Training and Assessment System (RDTES) in order to collect pre-learning data
The experience with virtual haptic simulators, their usefulness as a teaching tool for the development of skills and the realism of the simulator were positively valued training of students to prepare metal crowns

The results showed an improvement in the preparation skills of both groups

It simulates a realistic scan and cut of the tooth surface. The automatic performance evaluation system using the HMM model are accurate

VR significantly improved student performance
The simulator was effective in teaching manual skills for both tasks within the shortterm assessment
They were identified as generating elements of a more significant practice than one that is aimed at satisfying closed conceptual models

RDTES improves the operational outcome of ceramic crown preparation, including preparation, reduction, and preparation surface and profile 


\begin{tabular}{|c|c|c|c|c|}
\hline $\begin{array}{l}\text { Aliaga et al } \\
(22)\end{array}$ & $\begin{array}{l}2020, \\
\text { longitudinal } \\
\text { evaluation of } \\
\text { learning } \\
\text { methods }\end{array}$ & $\begin{array}{l}\text { To analyze the parameters } \\
\text { recorded by the Simodont }{ }^{\circledR} \\
\text { and the methacrylate block } \\
\text { qualifications during } \\
\text { preclinical practices to } \\
\text { validate if manual skills can } \\
\text { be evaluated with both } \\
\text { methodologies }\end{array}$ & $\begin{array}{l}82 \text { dental students in preclinical } \\
\text { practice with a two-year } \\
\text { follow-up. Identical designs } \\
\text { from two tests consisting of the } \\
\text { preparation of three cavities } \\
\text { with geometric shapes }\end{array}$ & $\begin{array}{l}\text { There was a statistically } \\
\text { significant improvement in } \\
\text { the mean scores in all the } \\
\text { parameters studied from the } \\
\text { first to the third year }\end{array}$ \\
\hline
\end{tabular}

\section{DISCUSSION}

This integrative review was intended to analyze current literature and research on the possibilities of improving educational quality through SVR in dental education. Studies were found describing how virtual simulators should be considered to save supervision and teaching time. Haptic simulator learning methods are educational options that dental educators might consider. Dental schools should evaluate the cost-benefit of incorporating virtual simulators with haptic technology to improve teaching $(1,6,13,17)$. Incorporating such technology into dental curricula can be costly. However, in the budget of a dental school, this tool can be calculated as an educational investment and a complement to the traditional methodology. Long-term prospective studies with experimental designs are suggested to evaluate student performance, learning outcomes, and profitability.

The use of simulators in the reviewed studies was a teaching tool with which dental students can develop management skills with virtual patients or simulators. They constitute an advanced technology that allows to build scenarios with a high degree of realism. However, simulation is not intended to develop communication with patients or to replace actual practice; rather, its purpose is to prepare students through the generation of manual, visual and auditory memory, as well as to provide feedback on learning in preparation for the clinic with real patients (23-27). 
It should be noted that there are still no uniform standards in dental education to implement digital tools. Such standards are necessary to ensure uniformity in teaching, which is particularly important for the international mobility of students and professionals (28).

Studies on highly complex surgical procedures should be assessed and carried out, using these virtual simulators, in order to prepare students for clinical situations with real patients. In countries like Colombia, virtual haptic simulator technology has not yet been implemented in dental schools.

Technology is advancing and has been driven lately by the COVID-19 pandemic. New simulators with different functions, 3D software and special programs for each specialty and theme will continue to be released every day. They will be useful for virtual dental education and practical learning from home or elsewhere.

In Latin America, institutions such as the University of Chile, a university in Brazil and the Peruvian University of Applied Sciences, have acquired virtual haptic simulators for learning dentistry. This has been very useful in the training of dentists in predoctoral and postdoctoral programs (29-31).

\section{CONCLUSIONS}

The studies reviewed show that virtual simulators are a modern virtual haptic alternative tool that has existed and continued to be incorporated into dental schools worldwide. They can be 
fundamental instruments to incorporate study plans for the development of manual skills and as a complement to existing training programs.

Simulation in dentistry is evolving, providing a safe environment with the possibility of better feedback and which emphasizes the importance of mentoring throughout the teaching-learning process. Virtual haptic simulation seek solutions to real-world challenges.

Virtual simulation in dentistry is not a substitute for clinical practice with real patients, but improves students' ability to perform dental procedures and develop preclinical manual skills.

\section{REFERENCES}

1. Llena C, Folguera S, Forner S, Rodrigez Lozano FJ. Implementation of augmented reality in operative dentistry learning. Europ J Dent Edu. 2017; 1(22): e122-e130. https://doi.org/10.1111/eje.12269

2. Fernández Sagredo M, Barrios Penna C. Percepción de la utilidad de los simuladores virtuales hápticos en educación odontológica por estudiantes, profesionales y académicos: estudio descriptivo observacional. FEM 2020; 23(2): 89-94.

3. Vásquez D. Ventajas, desventajas y ocho recomendaciones para la educación médica virtual en tiempos de covid-19. CES Med. 2020; (34)1: 14-27.

4. Gaitán Cepeda LA, Leyva Huerta ER, Cruz González R, Carmona RD, Rodríguez ME, Gómez AA. COVID-19 y el cirujano dentista. Una revisión integral. Rev Odontol Mex. 2019; 4(23): 207-215. 
5. Duran OG. Educación en odontología para las asignaturas de simulación preclínica en tiempos de Pandemia por COVID-19. J Dent Sci. 2020; 22(2): 11-13.

6. Plessas A. Computerized virtual reality simulation in preclinical dentistry: can a computerized simulator replace the conventional phantom heads and human instruction? Sim Healthcare. 2017; (12): 332-338. https://doi.org/10.1097/SIH.0000000000000250

7. Ta-Ko H, Chi-Hsun Y, Yu-Hsin H, Jen-Chyan W, Chun-Cheng H. Augmented reality (AR) and virtual reality (VR) applied in dentistry. Kaohsiung J Med Sci. 2018; (34): 243-248. https://doi.org/10.1016/j.kjms.2018.01.009

8. Morales R, Guevara J, Flores V, Robello J, Bazán. Use of virtual reality as a learning environment in dentistry. Gen Dent. 2019; 67(4): 21-27.

9. Lin WS, Chou JC, Charette JR, Metz MJ, Harris BT, Choi N. Creating virtual 3-dimensional models for teaching pre-clinical tooth preparation: students' usages and perceptions. Eur J Dent Educ. 2018 Aug; 22(3): e573-e581. https://doi.org/10.1111/eje.12354

10. Zafar S, Lai Y, Sexton C, Siddiqi A. Virtual reality as a novel educational tool in pre-clinical pediatric dentistry training: students’ perceptions. Inter J Pediatr Dent. 2020; 3(22): e573-e581. https://doi.org/10.1111/ipd.12648

11. Álvarez C, Coro G. Las nuevas unidades de simulación complejas como garantía de una enseñanza de calidad. Ciencia y Clínica. 2019; 309: 76-85.

12. Castillo S. Factores que se deben considerar al implementar estrategias de educación virtual en odontología. Univ Odontol. 2011; 30(65): 97-103.

13. Fernández M, Barrios C, Torrez P, Sáez R, Fonseca J. Percepción de la utilidad de los simuladores virtuales hápticos en educación odontológica por estudiantes, profesionales y académicos: estudio descriptivo observacional. FEM 2020; 23 (2): 89-94. 
14. Kikuchi H, Ikeda M, Araki K. Evaluation of a virtual reality simulation system for porcelain fused to metal crown preparation at Tokyo Medical and Dental University. J Dent Educ. 2013 Jun; 77(6): 782-92.

15. Vicent M, Joseph D, Amory C, Paoli N, Ambrosini P, Montier E. Contribution of haptic simulation to analogic training environment in restorative dentistry. J Dent Educ. 2020; 84(3): 367-376.

16. Rhienmora P, Haddawy P, Khanal P, Suebnukarn S, Dailey M. A virtual reality simulator for teaching and evaluating dental procedures. Intelligent Training. 2010: 396-405.

17. Murbay S, Neelakandan P, Chang JWW, Yeung S. Evaluation of the introduction of a dental virtual simulator on the performance of undergraduate dental students in the pre-clinical operative dentistry course. Eur J Dent Educ. 2020; 24: 5-16. https://doi.org/10.1111/eje.12453

18. González Bravo L, Fernández Sagredo M, Torres Martínez P, Barrios Penna C, Fonseca Molina J, Stanciu ID, Nistor N. Psychometric analysis of a measure of acceptance of new technologies (UTAUT), applied to the use of haptic virtual simulators in dental students. Eur J Dent Educ. 2020 Nov; 24(4): 706-714. https://doi.org/10.1111/eje.12559

19. Yamaguchi S, Yoshida Y, Noborio H, Murakam S, Imazato S. The usefulness of a haptic virtual reality simulator with repetitive training to teach caries removal and periodontal pocket probing skills. Dent Mater J. 2013; 32(5): 847-852. https://doi.org/10.4012/dmj.2013-174

20. Coro Montanet G, Suarez A, Gómez M, Gómez F. Didáctica de la introducción y uso de simuladores hápticos con entornos 3D en la docencia odontológica. Madrid, España: Universidad Europea; 2015. 
21. Luwei L, Zhou R, Ruyu Z, Siyang Y, Zhida S. Simulation training for ceramic crown preparation in the dental setting using a virtual educational system. Eur J Dent Educ. 2020; (24): 199-206. https://doi.org/10.1111/eje.12485

22. Aliaga I, Canal M, Vera V, Martin S, García E, Hernández O. Preclinical assessment methodology using a dental simulator during dental students' first and third years. J Oral Sci. 2020; 1(62): 119-121.

23. Shah P, Chong B. 3D imaging, 3D printing and 3D virtual planning in endodontics. Clin Oral Invest. 2018; (22): 641-654. https://doi.org/10.1007/s00784-018-2338-9

24. Kotecha R. Futuristic virtual reality training unveiled. Br Dent J. 2017; 8(222): 572.

25. Cristiani J. La simulación en la enseñanza en Odontología. Una herramienta de aprendizaje para la seguridad del paciente y la calidad de atención. Rev Fac Odontol. 2016; 1(9): 69-71.

26. Perry S, Bridges SM, Burrow MF. A review of the use of simulation in dental education. Simul Health. 2015 Feb; 10(1): 31-37. https://doi.org/10.1097/SIH.0000000000000059

27. Joda T, Gallucci G, Wismeijer D, Zitzmann. Augmented and virtual reality in dental medicine: A systematic review. Comp Biol Med. 2019; (108): 93-100.

28. Zitzmann NU, Matthisson L, Ohla H, Joda T. Digital undergraduate education in dentistry: a systematic review. Int J Environ Res Public Health. 2020 May 7; 17(9): 3269. https://doi.org/10.3390/ijerph17093269

29. Zúñiga Mogollones M, Ferri Sánchez G, Balltera Zuloaga C. Evaluación de la motivación académica tras implementar simulación háptica en estudiantes de primer año de la Universidad San Sebastián, en Santiago de Chile. FEM. 2018; 21(3): 137-141. 
30. Cayo Rojas CF, Agramonte Rosell RD. Desafíos de la educación virtual en Odontología en tiempos de pandemia COVID-19. Rev Cubana Estomatol; 2020; 57(3). http://www.revestomatologia.sld.cu/index.php/est/article/view/3341

31. Soares PV, de Almeida Milito G, Pereira FA, Reis BR, Soares CJ, de Sousa Menezes M, de Freitas Santos-Filho PC. Rapid prototyping and 3D-virtual models for operative dentistry education in Brazil. J Dent Educ. 2013 Mar; 77(3): 358-363. 